\title{
The Impact of E-learning system using Rank-based Clustering Algorithm (ESURBCA)
}

\author{
D.Suresh \\ M.Phil (CS) Research Scholar \\ SCSVMV University \\ Enathur, Kanchipuram
}

\author{
S.Prakasam, Ph.D \\ Assistant Professor \\ Department of CSA, SCSVMV University \\ Enathur, Kanchipuram
}

\begin{abstract}
E-learning is emerging as the new paradigm of modern education. Most of the e-learning systems have limitations such as scarcity of content, lack of intelligent search and context sensitive personalization problems, which are the challenging tasks for researchers. This motivated the author to take up this problem and the method implemented through this work suggests the instructors to use the combination of Elearning System Using Rank-Based Clustering Algorithm (ESURBCA) was designed. The main aim of the model developed is to get consistency in content delivery, quality content in learning materials, students self-learning concept, and performance improvement in their examination. A study has been conducted During June 2013 to September 2013, the author collected samples of 1631 from final year and Second year of BCA, B.SC and B.Sc-IT students were trained through e-learning system architecture and the objectives of this study is 1. To measure the effectiveness of E-learning System Using Rank-Based Clustering Algorithm (ESURBCA) among the students of Mercury College of arts and science And Sankara arts and Science College in concepts of Programming in JAVA Course. The newly designed E-learning System using Rank-Based Clustering Algorithm (EUSRBCA)shows an improvement over the existing systems with better results. From the various evaluations carried out, the performance of the system found to be good comparatively to other systems in e-learning domain.
\end{abstract}

\section{INTRODUCTION}

The concept of e-learning is expected to develop as technology advances. In order to boost the gains of e-learning market, the learning components are developed [16] that interoperate and co-operate. The great advantages of eLearning include liberating interactions between learners and instructors, or learners and learners, from limitations of time and space through the asynchronous and synchronous learning networks.

\section{RELATED WORK OF E-LEARNING}

This section presents a literature survey of the approaches used in e-learning environments. [15]Describes learning styles as the preferred ways through which learners interact with and process information in learning environments. Different views of learning styles were and are still discussed in the literature. Behaviorism, a reductionist view of human behavior, dominated the field in the first half of the 20th century. It was called reductionist because it used a black box approach based on empiricism, but such a simplified view left much to be desired. Rogers points out that "learning includes goals, purposes, intentions, choice and decision-making, and it is not at all clear where these elements fit into the learning cycle" [12].online learning has advantages over traditional face-to-face education [8], concerns include time, labor intensiveness, and material resources involved in running eLearning environments. The costly high failure rate of e-
Learning implementations discussed by [2] deserves attention from management and system designers.

Table 1.1 Comparative study of existing Data mining based e-learning methods

\begin{tabular}{|c|c|c|c|}
\hline $\begin{array}{l}\text { Learning } \\
\text { System }\end{array}$ & $\begin{array}{l}\text { Theory } \\
\text { Basis }\end{array}$ & $\begin{array}{l}\text { Instruction } \\
\text { al } \\
\text { Emphasis }\end{array}$ & $\begin{array}{l}\text { Result } \\
\text { S }\end{array}$ \\
\hline $\begin{array}{l}\text { Data Mining } \\
\text { In The E- } \\
\text { Learning } \\
\text { Domain } \\
\text { (Developed } \\
\text { By Margo } \\
\text { Hanna In } \\
\text { 2004). }\end{array}$ & $\begin{array}{l}\text { Awareness } \\
\text { of the } \\
\text { knowledge } \\
\text { economy } \\
\text { has come a } \\
\text { growing } \\
\text { consciousn } \\
\text { ess that HE } \\
\text { (Higher } \\
\text { Education) } \\
\text { a large } \\
\text { industry or } \\
\text { economic } \\
\text { sector. }\end{array}$ & $\begin{array}{l}\text { Agent based } \\
\text { approaches have } \\
\text { software } \\
\text { systems that } \\
\text { perform the } \\
\text { content mining. } \\
\text { Search engines } \\
\text { belong to this } \\
\text { class as do } \\
\text { intelligent } \\
\text { search engines, } \\
\text { information } \\
\text { filtering and } \\
\text { personalized } \\
\text { web agents. }\end{array}$ & $\begin{array}{l}\text { Online } \\
\text { events } \\
\text { are } \\
\text { becomin } \\
\mathrm{g} \quad \mathrm{a} \\
\text { promisin } \\
\mathrm{g} \text { area } \\
\text { for } \\
\text { research } \\
\text { and } \\
\text { develop } \\
\text { ment } \\
\text { when the } \\
\text { business } \\
\text { in } \\
\text { educatio } \\
\mathrm{n} \quad \text { is } \\
\text { growing } \\
\text { impressi } \\
\text { vely. }\end{array}$ \\
\hline $\begin{array}{l}\text { Predicting } \\
\text { Relationship } \\
\text { Between } \\
\text { Online } \\
\text { Questions } \\
\text { Theme And } \\
\text { Final Grade } \\
\text { (Developed } \\
\text { ByAbdous, } \\
\text { M., W., \&yen, } \\
\text { C.-J in2012). }\end{array}$ & $\begin{array}{l}\text { EDM } \\
\text { (Educationa } \\
1 \quad \text { Data } \\
\text { Mining) } \\
\text { And } \\
\text { regression } \\
\text { analysis to } \\
\text { analyze } \\
\text { Live Video } \\
\text { stream } \\
\text { (LVS) } \\
\text { students } \\
\text { online } \\
\text { learning } \\
\text { behaviours } \\
\text { And their } \\
\text { performanc } \\
\text { e in their }\end{array}$ & $\begin{array}{l}\text { Focused on } \\
\text { understanding } \\
\text { Live video } \\
\text { Streaming } \\
\text { (LVS) students } \\
\text { learning } \\
\text { behaviours, their } \\
\text { interaction and } \\
\text { their learning } \\
\text { outcomes. }\end{array}$ & $\begin{array}{l}\text { Students } \\
\text { learning } \\
\text { behaviou } \\
\text { rs, } \\
\text { ranging } \\
\text { from } \\
\text { active } \\
\text { participat } \\
\text { ion and } \\
\text { interactio } \\
n \quad \text { with } \\
\text { the } \\
\text { instructo } \\
\mathrm{r} \text { to a } \\
\text { lack of } \\
\text { participat } \\
\text { ion or } \\
\text { even of }\end{array}$ \\
\hline
\end{tabular}




\begin{tabular}{|c|c|c|c|}
\hline & course. & & $\begin{array}{l}\text { attendan } \\
\text { ce. }\end{array}$ \\
\hline $\begin{array}{l}\text { Mining } \\
\text { Educational } \\
\text { Data } \\
\text { improve } \\
\text { students' } \\
\text { performance( } \\
\text { Developed by } \\
\text { M.abu } \\
\text { Tair,Alaa M }\end{array}$ & $\begin{array}{l}\text { Educational } \\
\text { data mining } \\
\text { (EDM) to } \\
\text { improve } \\
\text { graduate } \\
\text { students } \\
\text { performanc } \\
\text { e and } \\
\text { overcome } \\
\text { the problem } \\
\text { of low } \\
\text { grade to } \\
\text { graduate } \\
\text { students. }\end{array}$ & $\begin{array}{l}\text { Data preparation } \\
\text { and } \\
\text { preprocessing of } \\
\text { the data set and } \\
\text { to get better } \\
\text { input data for } \\
\text { data mining } \\
\text { techniques some } \\
\text { preprocessing } \\
\text { for the collected } \\
\text { data before } \\
\text { loading the data } \\
\text { set to the data } \\
\text { mining software. } \\
\text { here we are used } \\
\text { some data } \\
\text { mining } \\
\text { techniques such } \\
\text { as association } \\
\text { rules, } \\
\text { classification,clu } \\
\text { steringand } \\
\text { outlier detection } \\
\text { used two ways } \\
\text { i)Distance- } \\
\text { Based Approach } \\
\text { and ii)Density } \\
\text { based approach. }\end{array}$ & $\begin{array}{l}\text { Data } \\
\text { mining } \\
\text { can be } \\
\text { used in } \\
\text { higher } \\
\text { educatio } \\
\mathrm{n} \\
\text { particula } \\
\text { rly to } \\
\text { improve } \\
\text { graduate } \\
\text { students } \\
\text { performa } \\
\text { nce. } \\
\text { Graduate } \\
\text { students } \\
\text { data } \\
\text { collected } \\
\text { from } \\
\text { college } \\
\text { of } \\
\text { science } \\
\text { technolo } \\
\text { gy in } \\
\text { khanyou } \\
\text { nis.the } \\
\text { data } \\
\text { include } \\
\text { 15years } \\
\text { period(1 } \\
993- \\
\text { 2007). }\end{array}$ \\
\hline $\begin{array}{l}\text { Using data } \\
\text { mining for e- } \\
\text { learning } \\
\text { decision } \\
\text { making(Devel } \\
\text { oped by David } \\
\text { Monk in2005) }\end{array}$ & $\begin{array}{l}\text { Learners } \\
\text { followed } \\
\text { when } \\
\text { offered the } \\
\text { course in } \\
\text { custom } \\
\text { Virtual } \\
\text { Learning } \\
\text { Environme } \\
\text { nt(VLE) } \\
\text { which is } \\
\text { structured } \\
\text { by } \\
\text { Task, } \\
\text { course } \\
\text { material } \\
\text { and } \\
\text { learning } \\
\text { resources. } \\
\text { Quickly } \\
\text { became }\end{array}$ & $\begin{array}{l}\text { The custom } \\
\text { VLE comprises } \\
\text { a number of } \\
\text { dynamic active } \\
\text { server pages } \\
\text { (ASP) } \\
\text { frameset, style } \\
\text { sheet and GUI } \\
\text { graphics. The } \\
\text { course content is } \\
\text { offered via } \\
\text { Three view- } \\
\text { materials, tasks } \\
\text { and library } \\
\text { resources. }\end{array}$ & $\begin{array}{l}\text { The } \\
\text { findings } \\
\text { that } \\
\text { indicate } \\
80 \% \text { of } \\
\text { users } \\
\text { accumul } \\
\text { ate less } \\
\text { than one } \\
\text { hour a } \\
\text { week } \\
\text { with the } \\
\text { course } \\
\text { materials } \\
\text { VLE } \\
\text { with } \\
\text { around } \\
\text { two- } \\
\text { thirds of } \\
\text { all users } \\
\text { acquiring } \\
\text { less than }\end{array}$ \\
\hline
\end{tabular}

\begin{tabular}{|c|c|c|c|}
\hline & $\begin{array}{l}\text { clear that } \\
\text { students } \\
\text { were } \\
\text { spending } \\
\text { little time } \\
\text { with the } \\
\text { course } \\
\text { materials } \\
\text { online and } \\
\text { the time } \\
\text { spent each } \\
\text { pages was } \\
\text { usually less } \\
\text { than 20 } \\
\text { seconds. }\end{array}$ & & $\begin{array}{l}30 \\
\text { minutes }\end{array}$ \\
\hline $\begin{array}{l}\text { Data Mining - } \\
\text { based } \\
\text { E-learning } \\
\text { system } \\
\text { (DMBELS) } \\
\text { Developed by } \\
\text { M.Prema and } \\
\text { S.Prakasam } \\
\text { in2013) }\end{array}$ & $\begin{array}{l}\text { The method } \\
\text { implemente } \\
\mathrm{d} \text { through } \\
\text { this work } \\
\text { suggests the } \\
\text { instructors } \\
\text { to use the } \\
\text { combinatio } \\
\mathrm{n} \text { of the } \\
\text { data mining } \\
\text { based e- } \\
\text { learning } \\
\text { system } \\
\text { (DMBELS) } \\
\text { was } \\
\text { designed. } \\
\text { The main } \\
\text { aim of the } \\
\text { model } \\
\text { developed } \\
\text { is to get } \\
\text { consistency } \\
\text { in content } \\
\text { delivery, } \\
\text { quality } \\
\text { content in } \\
\text { learning } \\
\text { materials, } \\
\text { students } \\
\text { self- } \\
\text { learning } \\
\text { concept, } \\
\text { and performanc } \\
\text { e } \\
\text { improveme } \\
\text { nt in their } \\
\text { examinatio } \\
\text { n. To } \\
\text { measure the } \\
\text { effectivenes } \\
\text { s of data } \\
\text { mining } \\
\text { technique } \\
\text { based e- } \\
\text { learning }\end{array}$ & $\begin{array}{l}\text { The text based } \\
\text { search engine is } \\
\text { created, which is } \\
\text { capable of } \\
\text { extracting the } \\
\text { documents from } \\
\text { open source } \\
\text { learning objects. } \\
\text { Document the } \\
\text { retrieval is based } \\
\text { on } \\
\text { occurrence of } \\
\text { computer } \\
\text { application } \\
\text { based } \\
\text { terminologies } \\
\text { and keywords } \\
\text { based on the } \\
\text { user search text. }\end{array}$ & $\begin{array}{l}\text { The } \\
\text { study } \\
\text { results } \\
\text { show } \\
\text { that the } \\
\text { systemati } \\
\text { c use of } \\
\text { Data } \\
\text { mining } \\
\text { based e- } \\
\text { learning } \\
\text { system } \\
\text { as a part } \\
\text { of the } \\
\text { instructio } \\
\text { nal } \\
\text { design } \\
\text { process } \\
\text { has improve } \\
\text { i the } \\
\text { quality } \\
\text { of teaching } \\
\text { and learning. }\end{array}$ \\
\hline
\end{tabular}




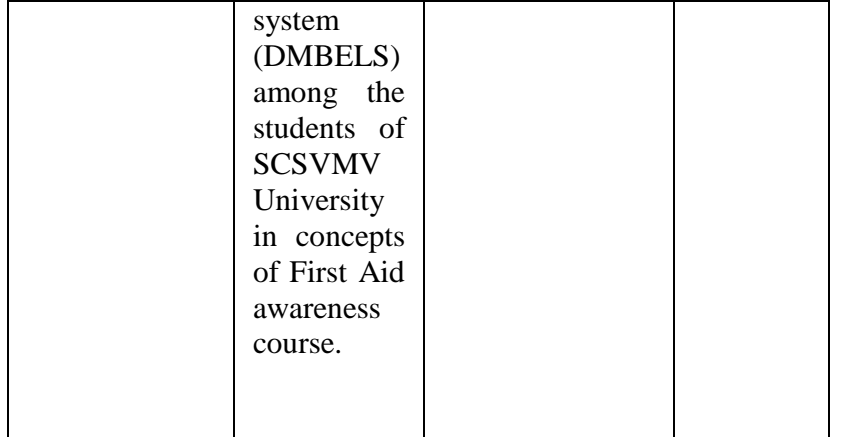

\section{ARCHITECTURE OF E-LEARNING SYSTEM}

In this work, architecture of e-Learning the combination of Elearning System Using Rank-Based Clustering Algorithm (ESURBCA). The Rank-Based Clustering Algorithm is capable of retrieving computer application based databases from the www and they are clustered based on the relativeness of the document to the user search. Clustering is based on page ranking which represents the level of relativeness for the retrieved clustered documents. Document retrieval is based on the occurrence of the computer application based terminologies and keywords based on the user search text.

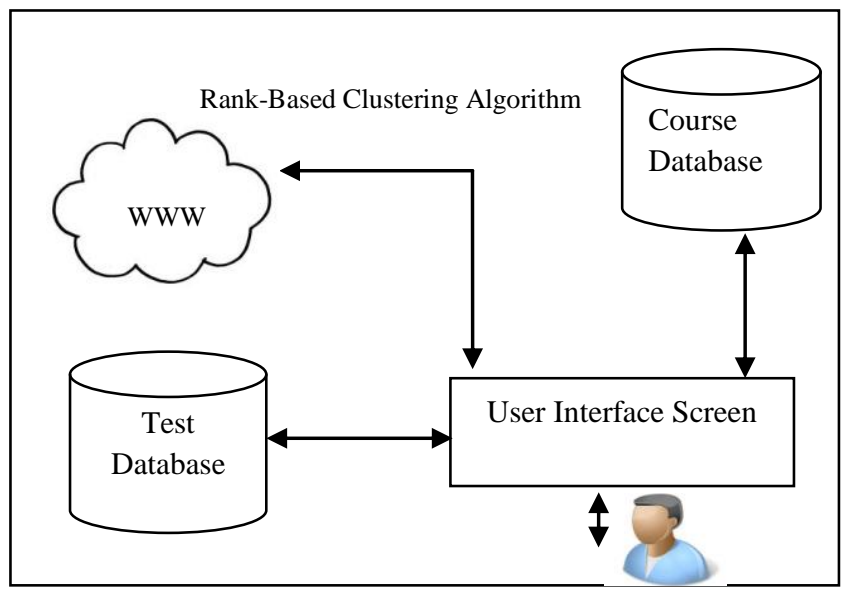

Fig 1.1 Architecture of E-Learning System using RankBased Clustering Algorithm

The below is the algorithm for Rank-Based Clustering Algorithm used in the Architecture of e-learning system Step1: Enter the searching text

Step2: Analyzed keyword and terminology from text

Step3: The relation set to identify the keyword from text

Step4: Through Word Net extract AlterNet keyword and terminology, store to the relation set list

Step5: The relation list, displayed related Docs from OSDBS

Step6: Extracted Docs stored to temporary folder

Step7: Doc list organizer rank and clustering the Docs on Rank based score

Step8: Rank score evaluation determinate was direct match keyword and found direct match terminologies.

\section{PERFORMANCE EVALUATION OF E-LEARNING}

Data mining-based e-learning system environment combined the pedagogical, communication and software tools integrated into one system that is used to promote learning. This helps to create an optimal knowledge building and learning environment for students.

A study has been conducted to measure the effectiveness of elearning system using Rank-Based Clustering Algorithm among the students of Mercury College of arts and science And Sankara arts and Science College in concepts of Java programming course.

The purpose of the study was twofold: (i) to measure the effectiveness of E-learning System Using Rank-Based Clustering Algorithm (ESURBCA) (ii) To find the student effectiveness (test mark) of E-learning System Using RankBased Clustering Algorithm (ESURBCA) among the students of Mercury College of arts and science And Sankara arts and Science College in concepts of Java programming course based on their marks before and after the e-learning course. This paper presents how the collected data are analyzed through appropriate statistical techniques and the results of data analysis.

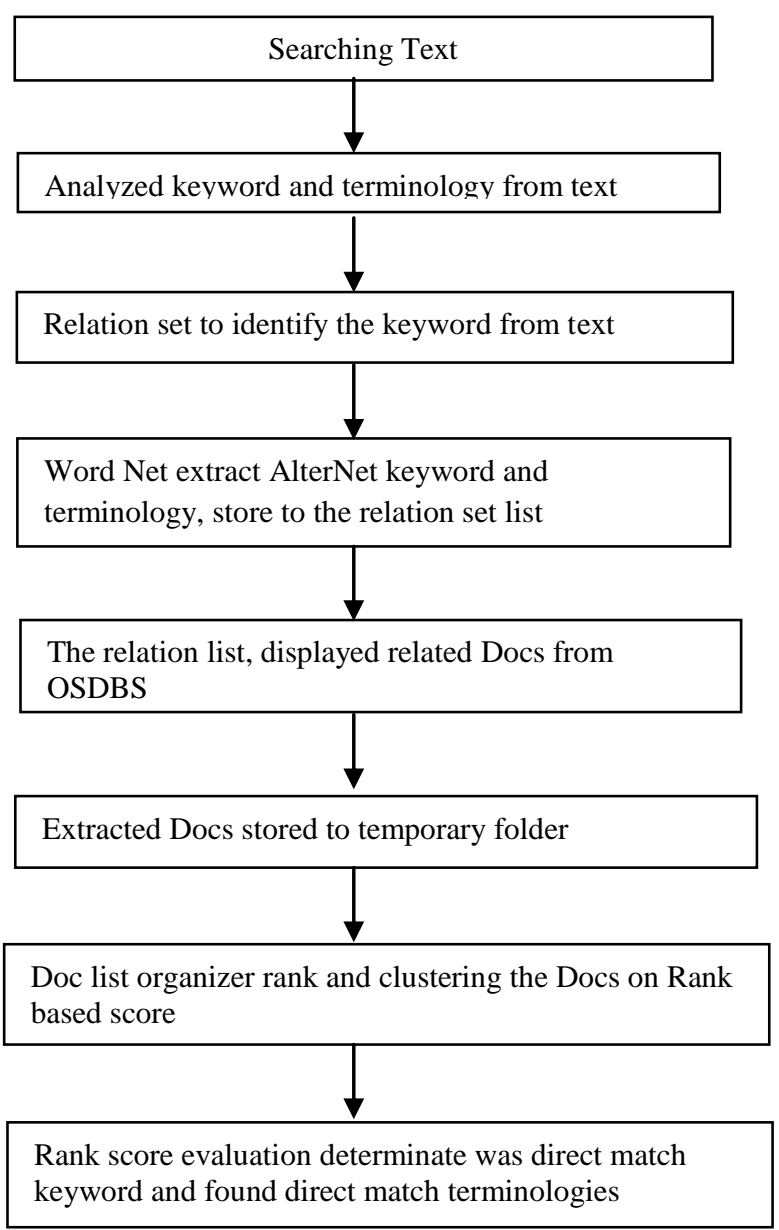

Fig 1.2 Rank-Based Clustering Algorithm 


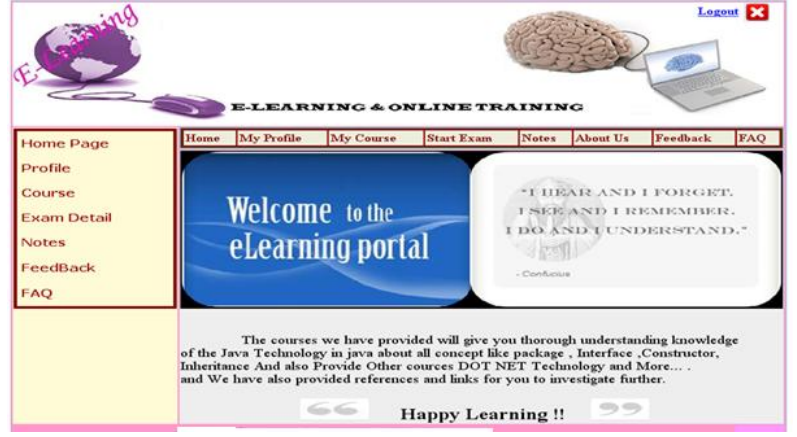

Fig 1.3 Implementing the Architecture of E-Learning System for Java Programming

\subsection{Performs Validation of E-learning system}

To find the student effectiveness (test mark) of To measure the effectiveness of E-learning System Using Rank-Based Clustering Algorithm (ESURBCA) among the students of Mercury College of arts and science And Sankara arts and Science College in concepts of Programming in JAVA Course based on their marks before and after the e-learning course during June 2013 to September 2013, the author collected samples of 1631 from final year and Second year of BCA,B.SC and B.Sc-IT students trained through e-learning system architecture.

Table 1.2 Number of respondents based on Course

\begin{tabular}{|c|c|c|c|c|c|c|c|c|c|}
\hline & \multicolumn{7}{|c|}{ Details of the learners } & \multirow[b]{2}{*}{$\begin{array}{c}\text { Tot } \\
\text { al }\end{array}$} \\
\hline & & $\begin{array}{l}\text { B.S } \\
\text { C- } \\
\text { CS } \\
\text { III }\end{array}$ & $\begin{array}{l}\text { B.S } \\
\text { C- } \\
\text { IT } \\
\text { III }\end{array}$ & $\begin{array}{c}\text { BC } \\
\text { A } \\
\text { III }\end{array}$ & $\begin{array}{l}\text { B.S } \\
\text { C - } \\
\text { CS } \\
\text { II }\end{array}$ & $\begin{array}{l}\text { B.S } \\
\text { C- } \\
\text { IT } \\
\text { II }\end{array}$ & $\begin{array}{c}\text { BC } \\
\text { A } \\
\text { II }\end{array}$ & $\begin{array}{l}\text { B.S } \\
\text { C }- \\
\text { CS } \\
\text { II }\end{array}$ & \\
\hline \multirow{2}{*}{$\begin{array}{l}\text { source } \\
\text { of } \\
\text { learni } \\
\text { ng }\end{array}$} & $\begin{array}{l}\text { Group A } \\
\text { (TTM) }\end{array}$ & 126 & 94 & 126 & 65 & 128 & 131 & 134 & 804 \\
\hline & $\begin{array}{l}\text { Group B } \\
\text { (MAABE } \\
\text { LS) }\end{array}$ & 125 & 93 & 135 & 72 & 129 & 138 & 135 & 827 \\
\hline \multicolumn{2}{|r|}{ Total } & 251 & 187 & 261 & 137 & 257 & 269 & 269 & $\begin{array}{r}163 \\
1\end{array}$ \\
\hline
\end{tabular}

\subsection{Hypothesis Tested}

\subsubsection{Research Hypothesis (H1)}

There will be a significant difference in the opinion and preferences of students between the traditional teaching method (TTM) and E-learning System Using Rank-Based Clustering Algorithm Null Hypothesis (Ho) there will not be a significant difference in the opinion and preferences of students between the traditional teaching method (TTM) and E-learning System Using Rank-Based Clustering Algorithm (ESURBCA) based on factors.

Normally ANOVA test requires the independent and dependent variables to test the significance. It is further classified into one-way and multi [MANOVA] analysis. The table 1.3 shows the significant difference in the opinion and preferences of students between the traditional teaching method (TTM) and E-learning System Using Rank-Based Clustering Algorithm (ESURBCA) based on factors (ESURBCA) based on factors.

Table 1.3 ANOVA Table

\begin{tabular}{|c|c|c|c|c|c|c|c|}
\hline & & $\begin{array}{c}\text { Sum } \\
\text { of } \\
\text { Squar } \\
\text { es }\end{array}$ & df & $\begin{array}{c}\text { Mean } \\
\text { Squar } \\
\text { e }\end{array}$ & $\mathbf{F}$ & Sig. & $\begin{array}{c}\text { Remar } \\
\text { ks }\end{array}$ \\
\hline $\begin{array}{l}\text { Feedback } \\
\text { about the } \\
\text { performan } \\
\text { ce in the } \\
\text { course }\end{array}$ & $\begin{array}{l}\text { Betwe } \\
\text { en } \\
\text { Groups } \\
\text { Within } \\
\text { Groups } \\
\text { Total }\end{array}$ & $\begin{array}{r}76.293 \\
\\
335.56 \\
8 \\
411.86 \\
1\end{array}$ & $\begin{array}{r}162 \\
9 \\
163 \\
0\end{array}$ & $\begin{array}{r}76.293 \\
.206\end{array}$ & $\begin{array}{r}370.36 \\
2\end{array}$ & .001 & $S$ \\
\hline $\begin{array}{l}\text { The } \\
\text { instructors } \\
\text { interest in } \\
\text { your } \\
\text { learning }\end{array}$ & $\begin{array}{l}\text { Betwe } \\
\text { en } \\
\text { Groups } \\
\text { Within } \\
\text { Groups } \\
\text { Total }\end{array}$ & $\begin{array}{r}48.368 \\
\\
353.94 \\
0 \\
402.30 \\
7\end{array}$ & $\begin{array}{r}162 \\
8 \\
162 \\
9\end{array}$ & $\begin{array}{r}48.368 \\
.217\end{array}$ & \begin{tabular}{r|}
222.47 \\
5 \\
\end{tabular} & \begin{tabular}{|c|}
.001 \\
2
\end{tabular} & $S$ \\
\hline $\begin{array}{l}\text { Utilization } \\
\text { of class } \\
\text { time }\end{array}$ & 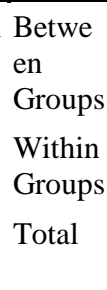 & $\begin{array}{r}127.97 \\
8 \\
\\
279.19 \\
8 \\
407.17 \\
5\end{array}$ & $\begin{array}{r}162 \\
8 \\
162 \\
9\end{array}$ & $\begin{array}{r}127.97 \\
8 \\
\\
.171\end{array}$ & $\begin{array}{r}746.23 \\
5\end{array}$ & \begin{tabular}{|c|}
.002 \\
1
\end{tabular} & $S$ \\
\hline $\begin{array}{l}\text { The } \\
\text { instructors } \\
\text { overall } \\
\text { organizati } \\
\text { on of the } \\
\text { course }\end{array}$ & $\begin{array}{l}\text { Betwe } \\
\text { en } \\
\text { Groups } \\
\text { Within } \\
\text { Groups } \\
\text { Total }\end{array}$ & $\begin{array}{r}36.125 \\
\\
358.58 \\
7 \\
394.71 \\
2\end{array}$ & $\begin{array}{r}162 \\
8 \\
162 \\
9\end{array}$ & $\begin{array}{r}36.125 \\
.220\end{array}$ & $\begin{array}{r}164.01 \\
0\end{array}$ & $\begin{array}{c}.001 \\
4\end{array}$ & $S$ \\
\hline $\begin{array}{l}\text { Continuity } \\
\text { from one } \\
\text { class } \\
\text { meeting to } \\
\text { the next } \\
\text { meeting }\end{array}$ & $\begin{array}{l}\text { Betwe } \\
\text { en } \\
\text { Groups } \\
\text { Within } \\
\text { Groups } \\
\text { Total }\end{array}$ & $\begin{array}{r}113.90 \\
6 \\
293.52 \\
0 \\
407.42 \\
6\end{array}$ & $\begin{array}{r}162 \\
8 \\
162 \\
9\end{array}$ & $\begin{array}{r}113.90 \\
6 \\
\\
.180\end{array}$ & $\begin{array}{r}631.77 \\
7\end{array}$ & $\begin{array}{c}.001 \\
7\end{array}$ & $S$ \\
\hline $\begin{array}{l}\text { The } \\
\text { instructors } \\
\text { assessmen } \\
\text { t of your } \\
\text { progress } \\
\text { in the } \\
\text { course }\end{array}$ & $\begin{array}{l}\text { Betwe } \\
\text { en } \\
\text { Groups } \\
\text { Within } \\
\text { Groups } \\
\text { Total }\end{array}$ & $\begin{array}{r}112.02 \\
7 \\
301.20 \\
2 \\
413.22 \\
9\end{array}$ & $\begin{array}{r}162 \\
8 \\
162 \\
9\end{array}$ & $\begin{array}{r}112.02 \\
7 \\
\\
.185\end{array}$ & $\begin{array}{r}605.50 \\
8\end{array}$ & $\begin{array}{c}.002 \\
8\end{array}$ & $S$ \\
\hline $\begin{array}{l}\text { Learning } \\
\text { materials } \\
\text { used in } \\
\text { the } \\
\text { courses }\end{array}$ & $\begin{array}{l}\text { Betwe } \\
\text { en } \\
\text { Groups } \\
\text { Within } \\
\text { Groups }\end{array}$ & $\begin{array}{r}66.353 \\
418.61 \\
0\end{array}$ & $\begin{array}{r}162 \\
8\end{array}$ & .257 & $\begin{array}{r}258.05 \\
0\end{array}$ & $\begin{array}{c}.002 \\
2\end{array}$ & $S$ \\
\hline
\end{tabular}




\begin{tabular}{|c|c|c|c|c|c|c|c|}
\hline & & $\begin{array}{c}\text { Sum } \\
\text { of } \\
\text { Squar } \\
\text { es }\end{array}$ & df & $\begin{array}{c}\text { Mean } \\
\text { Squar } \\
\text { e }\end{array}$ & $\mathbf{F}$ & Sig. & $\underset{\text { ks }}{\text { Remar }}$ \\
\hline & Total & $\begin{array}{r}484.96 \\
3 \\
\end{array}$ & $\begin{array}{r}162 \\
9 \\
\end{array}$ & & & & \\
\hline & $\begin{array}{l}\text { Within } \\
\text { Groups }\end{array}$ & $\begin{array}{r}351.50 \\
7\end{array}$ & $\begin{array}{r}162 \\
8\end{array}$ & .216 & & & $\mathrm{~S}$ \\
\hline & Total & $\begin{array}{r}395.69 \\
1\end{array}$ & $\begin{array}{r}162 \\
9\end{array}$ & & & & \\
\hline & $\begin{array}{l}\text { Within } \\
\text { Groups }\end{array}$ & $\begin{array}{r}341.81 \\
1\end{array}$ & $\begin{array}{r}162 \\
9\end{array}$ & .210 & & & S \\
\hline & Total & $\begin{array}{r}375.17 \\
5\end{array}$ & $\begin{array}{r}163 \\
0\end{array}$ & & & & \\
\hline & $\begin{array}{l}\text { Within } \\
\text { Groups }\end{array}$ & $\begin{array}{r}351.78 \\
1\end{array}$ & $\begin{array}{r}162 \\
9\end{array}$ & .216 & & & S \\
\hline & Total & $\begin{array}{r}406.77 \\
0\end{array}$ & $\begin{array}{r}163 \\
0\end{array}$ & & & & \\
\hline $\begin{array}{l}\text { Availabilit } \\
\text { y to assist } \\
\text { students in } \\
\text { or outside } \\
\text { of class }\end{array}$ & $\begin{array}{l}\text { Betwe } \\
\text { en } \\
\text { Groups } \\
\text { Within } \\
\text { Groups }\end{array}$ & $\begin{array}{r}105.55 \\
8 \\
301.03 \\
2\end{array}$ & $\begin{array}{r}162 \\
9\end{array}$ & $\begin{array}{r}105.55 \\
8 \\
\\
.185\end{array}$ & $\begin{array}{r}571.21 \\
5\end{array}$ & .001 & \\
\hline & Total & $\begin{array}{r}406.59 \\
0\end{array}$ & $\begin{array}{r}163 \\
0 \\
\end{array}$ & & & & $\mathrm{~S}$ \\
\hline $\begin{array}{l}\text { Simulatio } \\
\mathrm{n} \text { of } \\
\text { interest in }\end{array}$ & $\begin{array}{l}\text { Betwe } \\
\text { en } \\
\text { Groups }\end{array}$ & 64.919 & 1 & 64.919 & $\begin{array}{r}270.56 \\
8\end{array}$ & .002 & \\
\hline (11) & $\begin{array}{l}\text { Within } \\
\text { Groups }\end{array}$ & $\begin{array}{r}390.85 \\
8\end{array}$ & $\begin{array}{r}162 \\
9\end{array}$ & .240 & & & $S$ \\
\hline & Total & $\begin{array}{r}455.77 \\
7\end{array}$ & $\begin{array}{r}163 \\
0 \\
\end{array}$ & & & & \\
\hline $\begin{array}{l}\text { Facilitatio } \\
\text { n of } \\
\text { learning }\end{array}$ & $\begin{array}{l}\text { Betwe } \\
\text { en } \\
\text { Groups }\end{array}$ & 27.895 & 1 & 27.895 & $\begin{array}{r}128.42 \\
0\end{array}$ & $\begin{array}{c}.002 \\
0\end{array}$ & \\
\hline & $\begin{array}{l}\text { Within } \\
\text { Groups }\end{array}$ & $\begin{array}{r}353.84 \\
3\end{array}$ & $\begin{array}{r}162 \\
9\end{array}$ & .217 & & & S \\
\hline & Total & $\begin{array}{r}381.73 \\
8\end{array}$ & $\begin{array}{r}163 \\
0\end{array}$ & & & & \\
\hline & $\begin{array}{l}\text { Within } \\
\text { Groups }\end{array}$ & $\begin{array}{r}363.51 \\
7\end{array}$ & $\begin{array}{r}162 \\
9\end{array}$ & .223 & & & $S$ \\
\hline & Total & $\begin{array}{r}405.57 \\
1\end{array}$ & $\begin{array}{r}163 \\
0\end{array}$ & & & & \\
\hline
\end{tabular}

Depending on the Feedback about the performance in the course, among the traditional teaching method (TTM) and Elearning System Using Rank-Based Clustering Algorithm (ESURBCA), there is significant difference exist among the learners. It is proved through the table 1.3 that significance is 0.001 which is less than 0.05. So the Null Hypothesis is rejected.

There is a significant difference between the traditional teaching method (TTM) and E-learning System Using Rank-
Based Clustering Algorithm (ESURBCA), among the learners, in the following factors (Fig 1.3), Feedback about the performance in the course, The instructors interest in your learning, The instructors assessment of your progress in the course Utilization of class time, The instructors overall organization of the course, Continuity from one class meeting to the next meeting, Learning materials used in the courses, Availability to assist students in or outside of class was, Simulation of interest in the course was and Facilitation of learning , are in favour of E-learning System Using RankBased Clustering Algorithm (ESURBCA) method at the level of significance of 0.05 .

Table 1.4 Mean Values

\begin{tabular}{|c|l|c|c|}
\hline S.NO & \multicolumn{1}{|c|}{ FACTORS } & TTM & ESURBCA \\
\hline 1 & $\begin{array}{l}\text { Feedback about the } \\
\text { performance in the } \\
\text { course }\end{array}$ & 2.127 & 2.407 \\
\hline 2 & $\begin{array}{l}\text { The instructors } \\
\text { interest in your } \\
\text { learning }\end{array}$ & 2.16 & 2.395 \\
\hline 3 & $\begin{array}{l}\text { Utilization of class } \\
\text { time }\end{array}$ & 2.085 & 2.428 \\
\hline 4 & $\begin{array}{l}\text { The instructors overall } \\
\text { organization of the } \\
\text { course }\end{array}$ & 2.197 & 2.41 \\
\hline 5 & $\begin{array}{l}\text { Continuity from one } \\
\text { class meeting to the } \\
\text { next meeting }\end{array}$ & 2.09 & 2.416 \\
\hline 6 & $\begin{array}{l}\text { The instructors } \\
\text { assessment of your } \\
\text { progress in the course }\end{array}$ & 2.081 & 2.405 \\
\hline 7 & $\begin{array}{l}\text { Learning materials } \\
\text { used in the courses }\end{array}$ & 2.143 & 2.408 \\
\hline 8 & $\begin{array}{l}\text { Availability to assist } \\
\text { students in or outside } \\
\text { of class was }\end{array}$ & $\begin{array}{l}\text { Simulation of interest } \\
\text { in the course was }\end{array}$ & 2.143 \\
\hline 10 & $\begin{array}{l}\text { Facilitation of } \\
\text { learning was }\end{array}$ & 2.406 \\
\hline & & \\
\hline
\end{tabular}




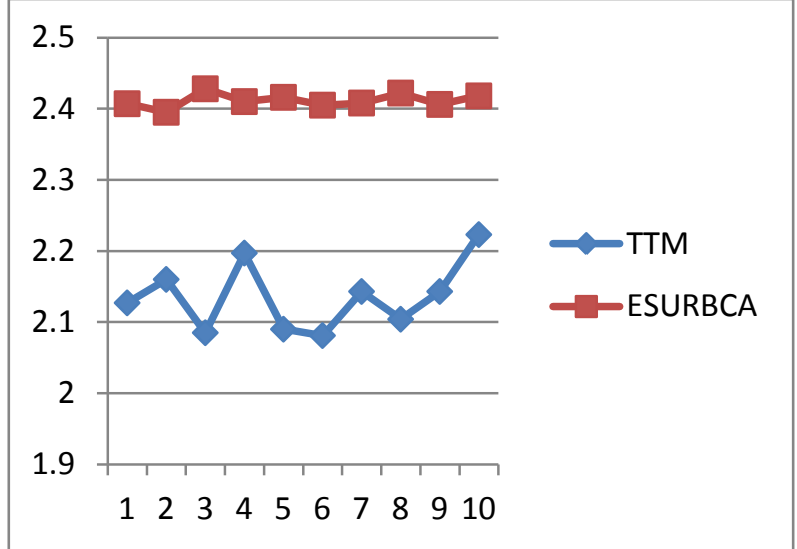

Fig 1.4 Effectiveness of ESURBCA

\section{CONCLUSION}

The concepts of e-learning system have been outlined. Elearning is considered in the context of formally and systematically organized teaching and learning activities, in which the instructor and the learner(s) use ICT to facilitate their interaction and collaboration. The use of data mining based e-learning system will definitely impact the quality of the education that is delivered and the deliverability of information through knowledge and information sharing. The newly designed E-learning System using Rank-Based Clustering Algorithm (EUSRBCA)shows an improvement over the existing systems with better results. From the various evaluations carried out, the performance of the system found to be good comparatively to other systems in e-learning domain.

\section{REFERENCES}

[1] Ajzen, I., \& Fishbein, M. (1977). Attitude-behavior relations: a theoretical analysis and review of empirical research. Psychological Bulletin, 84, 888-918.

[2] Arbaugh, J. B., \& Duray, R. (2002). Technological and structural characteristics, student learning and satisfaction with web-based courses - An exploratory study of two on-line MBA programs. Management Learning, 33(3), 331-347.

[3] Aronen, R., \& Dieressen, G. (2001). Improvement equipment reliability through e-Learning. Hydrocarbon Processing, 47-57.

[4] Bhattacherjee, A. (2001). Understanding information systems continuance: an expectation confirmation model. MIS Quarterly, 25(3), 270-351.

[5] Katz, Y. J. (2000). The comparative suitability of three ICT distance learning methodologies for college level instruction. Educational Media International, 37(1), 2530.
[6] Katz, Y. J. (2002). Attitudes affecting college students' preferences for distance learning. Journal of Computer Assisted Learning, 18,2-9

[7] Lewis, C. (2002). Driving factors for e-Learning: an organizational perspective. Perspectives, 6(2), 50-54. Lin, Cathy S., Wu, S., \& Tsai, R. J. (2005). Integrating perceived playfulness into expectation-confirmation model for web portal context. Information \& Management, 42, 683-693.

[8] Piccoli, G., Ahmad, R., \& Ives, B. (2001). Web-based virtual learning environments: a research framework and a preliminary assessment of effectiveness in basic IT skill training. MIS Quarterly, 25(4), 401-426.

[9] Wu, J. P., Tsai, R. J., Chen, C. C., \& Wu, Y. C. (2006). An integrative model to predict the continuance use of electronic learning systems: hints for teaching. International Journal on E-Learning, 5(2), 287-302.

[10] Khairil Imran Ghauth and, Nor Aniza Abdullah, (2009) An Empirical Evaluation Of Learner Performance In ELearning Recommender Systems And An Adaptive Hypermedia System, pp 141-152.

[11] Jonassen, D. H., Computers in the Classroom, Englewood Cliffs, NJ:Merrill, Keefe, J. W. (1987), in "Learning Style".

[12] Peters, J., Jarvis, P. et al., Adult Education, San Francisco, CA, Ed Rogers, A., Teaching Adults, Buckingham: Open University Press

[13] Jemni, M., \& Nasraoui, O. (2009). Automatic recommendations for e-learning personalization based on web usage mining techniques and information retrieval. Educational Technology \& Society, 12(4), 30-42.

[14] Liang, G., Weining, K. \& Junzhou, L. (2006). Courseware recommendation in e-learning system. Advances in Web Based Learning - ICWL2006, Springer Berlin/Heidelberg, 10-24.

[15] Kerkiri, T., Manitsaris, A. \& Mavridou, A. (2007). Reputation metadata for ecommending personalized elearning resources. Proceedings of the Second International Workshop on Semantic Media Adaptation and Personalization, Uxbridge, 110-115.

[16] Namuth, Fritz, King, \& Boren, 2005 Principles of sustainable learning object libraries. Interdisciplinary journal of knowledge and Learning objects, 1,181-196. Available at http://ijklo.org/volume1/v1p181196Namuth.pdf

[17] Peters, J., Jarvis, P. et al., Adult Education, San Francisco, CA, Ed Rogers, A., Teaching Adults, Buckingham: Open University Press, 1996.

[18] M.Prema and S.Prakasam Effectiveness of Data Mining - based E-learning system (DMBELS) International Journal of Computer Applications (0975 - 8887) Volume 66- No.19, March 2013. 